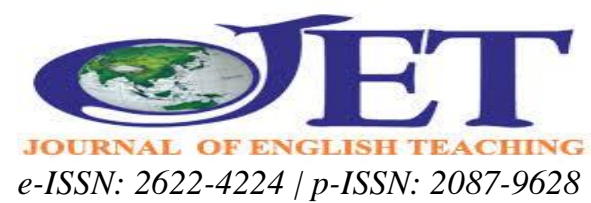

\title{
The Effect of Using Karaoke Activities on Students' English Pronunciation
}

\author{
Karsono \\ nieldaniel250@gmail.com \\ English Education Department, \\ Universitas Kristen Indonesia Jakarta
}

DOI: http://dx.doi.org/10.33541/iet.v5i3.1311

\begin{abstract}
Karaoke is basically a form of entertainment involving the use of a karaoke machine which provides audio, visual, and also textual information at the same time. Having these features, karaoke offers some promising and potential uses to the language teaching, because it involves both linguistic processing and language articulation. This research aims at investigating the effect of karaoke activities on students' English pronunciation. Employing the one-group pretest-posttest design, 34 students of the $\mathrm{X}$ MIPA 3 class of SMA Negeri 14 Jakarta in academic year 2018/2019 learnt pronunciation through karaoke activities in five sessions. Using Wilcoxon Sign Ranks Test, the hypothesis test revealed that karaoke activities significantly affected the tenth graders' English pronunciation at SMA Negeri 14 Jakarta.
\end{abstract}

Keywords: karaoke activities, English pronunciation, experimental study

\section{INTRODUCTION}

Its growing role as an essential part of daily communication among people around the world has encouraged more and more people to learn English in order to be able to speak in it. Richards and Renandya (2002, p. 201) stated that the majority of the world's language learners study English for developing speaking proficiency. However, it has been widely noticed that many EFL learners encounter various difficulties to master English speaking. Hinkel (2005) asserted that speaking is "the most complex and difficult skill to master" (p. 485). One of the causes why speaking difficult to master in an EFL setting concerns with pronunciation, which, according to Fraser (2000), is the most important elements of oral communication skill. To speak, one essentially needs various sub-skills, including vocabulary, grammar, and pragmatics. Yet, the most important of these skills is pronunciation. Adams-Goertel (2013) affirmed that for every EFL learner or non-native speaker, pronunciation is essential for distinguishing meanings or to produce comprehensible utterances. A good mastery of pronunciation also increases their intelligibility and listening comprehension. Such high importance of pronunciation is shown by the fact that although a speech contains some mistakes in vocabulary, grammar, and pragmatics, with acceptable pronunciation, it is still understandable. But, despite being accurate in other areas, with bad pronunciation, a 
speech would be very difficult to understand. Hişmanoğlu (2006, p. 101) accentuated that pronunciation is "a key to gaining full communicative competence". Julia (2002) even stated without pronunciation there would be no spoken language and no oral communication.

One of the major causes why English pronunciation is difficult for EFL learners is their lack of contact with English native speakers which then provides minimal exposure of English sounds. To understand and acquire English pronunciation well, EFL learners need to extensively and intensively listen to and practice it. The extensive and intensive listening will familiarize the learners with the English sound system, and language learners' familiarity with the sound system of the target language is very essential for them to master the language (Pardede, 2007). After being familiar, the learners should then practice producing the sounds in a contextual situation so that the practice is meaningful and motivating.

Various studies have revealed that one of the effective means for providing EFL learners with contextual, meaningful and motivating way is songs, because the elements of songs, including melody, harmony, timbre, rhythm, tempo, and lyrics can decrease affective barriers and helps students be more relaxed. These elements also increase motivation, promote recall and memory, and develop language skills (Pardede, 2019). The repetitive nature of songs and the inherent supra-segmental features in them make them effective to use for pronunciation development (Lems, 2001; Wong \& Perrachione, 2006). Limited studies focusing on the use of karaoke showed that it is an effective activity for using songs to develop English skills, including pronunciation. McGall (2008) reported that frequent use of karaoke in classes resulted in improvements in reading comprehension of special need students. In addition, Renfigo's (2009) study showed that karaoke is well received by the language learners and is perceived to help students improve their English.

Considering the meager number of studies investigating karaoke activity in EFL classrooms, particularly for pronunciation development, while it affords promising opportunities and prospects for language learning and teaching, this study was an attempt to fill in the gap. The results of this study will hopefully give information about the significant effect of karaoke activity on the pronunciation of students. In relation to that, the problems to be tackled in this study is specifically stated as follows: "Is there any significant effect of using karaoke activities on students' English pronunciation at 10 th grade of SMA Negeri 14 Jakarta?"

\section{LITERATURE REVIEW}

\section{Importance of Pronunciation}

In a general sense, pronunciation is the way in which a word or a language is spoken. Yates (2002) stated that pronunciation is the production of sounds that someone uses to make meaning. It refers to the way of producing the sounds that are used to make meaning when someone speaks (Gilakjani, 2012); Yates \& Zielinski, 2009). Pronunciation includes segmental element (consonants and vowels), suprasegmental features, or the features of speech beyond the level of the individual segments, (stress, timing, rhythm, intonation, phrasing) of a language, and how the voice is described (voice quality). All of these elements work together when a person talks so that problems in one part can influence on the other and this can make his pronunciation easy or difficult to comprehend. 
Realizing these features, no wonder why pronunciation is an important aspect of spoken language proficiency and a component of language and communication that conveys many different kinds of meaning as well. It covers linguistic competence at micro and macro levels for both production and perception of speech, including the segmental level of individual phonemes (consonants and vowels) and the supra segmental or prosodic level of connected speech that includes linking and articulation, tone and intonation, stress and rhythm, and voice quality and articulatory setting (Pennington \& Revel, 2019). Pardede (2019) accentuated that good pronunciation skills are a key element to one's ability to speak in every language because clear speech requires accurate production of various factors, e.g., phonemes, stress, linking, rhythm, and intonation. Pare (2015) added that having good pronunciation is very important in communicating using English. Therefore, it is an aspect of language that should be learned.

The popularity of the communicative language learning approach which emphasizes that the main goal of a language program is to enable the learners to communicate in the target language has essentially grown the awareness of the essential role of pronunciation to achieve a successful communication. A speaker's English ability is essentially judged based on his pronunciation. Weak pronunciation automatically causes a negative impact on his overall language ability because bad pronunciation is very difficult to comprehend and requires greater effort and concentration from the listeners. Bad pronunciation can emerge misunderstandings and even spoil communication. On the other hand, a speaker with an acceptable pronunciation helps his listeners to judge his overall language ability much more effectively, although he commits some grammatical mistakes (Gilakjani, 2012). As a consequence, good pronunciation provides valuable confidence for speakers, and since confidence facilitates learning, the better a learner's pronunciation the higher his language acquisition will be. Gilakjani (2012) posited that good pronunciation leads to learning while bad pronunciation promotes to great difficulties in language learning. In short, good pronunciation is not only necessary in communicating using a language but also in the process of learning a language.

\section{Negligence of Pronunciation Instruction in EFL}

Despite its high importance in language learning, pronunciation instruction has long been neglected in the second language (SL) and foreign language (FL) teaching. Even up to the present day, it is seldom taught by teachers in foreign language classrooms. Lin, Fan, and Chen (1995) found that for Taiwanese English teachers, English pronunciation is not significant for their learners and just a few tests will require learners to indicate their skills pertinent to English pronunciation. Dalton (2002) reported that in Mexico pronunciation is regarded as "the Cinderella of language teaching" and a little emphasis was placed on teaching it. According to Wei and Zhou (2002), English pronunciation was neglected in some universities in Thailand. In Indonesia, although secondary school students really need to learn pronunciation, most teachers do not know what to teach and how to teach it (Moedjito, 2008).

According to Gilbert (2008), pronunciation instruction negligence in EFL classes is caused by two main reasons. First, many EFL teachers lack time to deal with pronunciation, and if they have enough time more attention is paid to drills that disappoint both learners and teachers in relation to the learning and teaching English pronunciation. Second, most learners are not certain about their English pronunciation 
as they are about their grammar and lexis knowledge. They get these psychological factors unconsciously and prohibit them from improving their understandability. Gilakjani and Sabouri (2016) reported that Iranian English teachers ignored pronunciation teaching due to their lack of time, motivation, resources, materials, and educational facilities. According to Fraser (2000) and Macdonald, (2003), the factors that cause pronunciation instruction avoidance are: teachers often feel that they are inadequately prepared to teach it; pronunciation instruction is not appropriately emphasized in curricula, and suitable materials for teaching pronunciation are often unavailable.

\section{The Goals of English Pronunciation Instruction}

In the previous decades, pronunciation instruction was directed to let the learners attain 'perfect' pronunciation, i.e. "native-like" pronunciation. However, current studies have shown that the realistic goal of pronunciation instruction in the EFL context is to acquire such 'perfect' pronunciation but to produce a comprehensible and intelligible speech (Gilakjani, 2012). Morley (1991) supported this by accentuating that the goal of pronunciation should be changed from the attainment of 'perfect' pronunciation to the more realistic goals of developing functional intelligibility, communicability which grow self-confidence and develop speech monitoring abilities and speech modification strategies for use beyond the classroom. In this context, intelligibility refers to "the extent to which a listener actually understands an utterance", and comprehensibility is "a listener's perception of how difficult it is to understand an utterance" (Derwing \& Munro, 2005, p. 385). The overall aim of these goals is to develop students' spoken English that is easy to understand, serves his individual needs, and allows a positive image of himself as a speaker of a foreign language. Such new goals are reasonable and thus could avoid the frustration experienced by many learners in the trials to acquire a 'perfect' pronunciation.

To achieve these goals, Pardede's (2007) literature review suggests teaching pronunciation in a meaningful and motivating way. Such a way is needed because good pronunciation is closely linked with clear oral communication. Consequently, to develop pronunciation, the learners should be placed in a meaningful and contextual situation, rather than present them with a series of isolated sentences. This way could be realized by implementing the following strategies: providing meaningful materials, using songs, games, and tongue twisters, and assessing students' progress. Since this study focused on the effect of karaoke activities towards pronunciation the following subsections review the use of songs in EFL classroom and karaoke activities for improving pronunciation.

\section{Using Songs in Pronunciation Instruction}

In the EFL classroom using songs seems interesting to apply because it deals with pleasant music and hobby experience. Chen (2011) claimed that music experiences are creative endeavors that can strengthen students' cognitive and mental abilities, and found that listening to music stimulates a positive mood and cognitive growth. He also agreed that English nursery rhymes and chants are effective tools for students learning English. In addition, music is everlasting. Since music is eternal in nature, learners can memorize songs and keep on practicing the tunes and lyrics they have learned.

Based on his literature review, Pardede (2019) stated that the integration of music and songs has some positive effects. First, they promote language acquisition because 
their motivational features facilitate a more relaxed learning environment and their cognitive and linguistic facets boost vocabulary and language learning. Second, they help teachers to create a learning environment with various activities that nurture imagination. The use of music and songs in foreign languages also offers teachers with resourceful possibilities for motivating and activating students. Third, recurrent use of music in language learning also provides a refreshing means to support different language skills development and provides an encouraging way to support students' cultural awareness. In addition, linking music with language learning would produce an interesting and innovative avenue for the language classroom. Carlsson (2015) argued that including music in language teaching have been investigated in multiple studies worldwide and many researchers reach a positive result, the use of songs can develop and integrate the four basic skills: reading, writing, listening and speaking, in a natural and harmonic way in the EFL classes.

In relation to the use of songs to teach pronunciation, Harmer (2000) stated that music is a powerful stimulus for student engagement for it speaks directly to everyone's emotions while still allowing him to use his brain to analyze it and its effects if he so wishes. Thus, songs are a good resource for pronunciation teaching due to several reasons, including: (1) they are fun; (2) they promote mimics, gestures, etc. associated to the meaning; (3) they are good to introduce suprasegmental phonetics (stress, rhythm, and intonation); (4) they motivate students to play a participative role; (5) they can be applied to comprehension stages (listening) or production (singing); (6) songs are available for all levels and ages; and (7) they facilitate students to learn English very easily through echoic memory.

Pardede's (2019) literature review reveals that songs can easily be used to practice language skills and develop English vocabulary, grammar, and pronunciation in various ways. However, to suit their teaching contexts, teachers may require to adjust the ideas offered by the literature. Some of the activities intended for younger learners might not be appropriate for older students. Nevertheless, activities that are probably seem trivial on paper can work effectively when used at the right time and in the right context. For instance, even adult students can enjoy chanting the letters of the alphabet in a rap style (Arleo, 2000).

\section{Karaoke Activity for Improving Pronunciation}

The term karaoke was adopted from Japanese kara (means "empty" and oke (the short version of okesutora, meaning orchestra). It is a device that plays instrumental accompaniments for a selection of songs to which the user sings along with the music. It is "also a form of entertainment involving the use of a karaoke machine" (Meriam, 2008). Karaoke is essentially an extension of resorting to songs as classroom materials. It provides audio, visual, and textual information at the same time so that the one or more learner can sing along the melody and read the lyrics running on the screen while the other learners listen to the performance. Thus, karaoke singing necessitates a screen (a television, PC monitor or data show projector) to view the lyrics to be sung. Good quality sound output can add to the quality of karaoke experience, though portable speakers can be good enough to use in small classes even. A microphone is desirable for the best effect because a microphone is helpful to create a sense of real singing and helps singers feel more relaxed. It also gives the singers the opportunity to hear themselves through the speakers or sometimes over headphones. 
The real function of karaoke is that it mutes the voice and shows one the lyrics so one can listen to the rest of the musical instruments along with reading the words to pronounce or sing. Thus, although karaoke was formerly used for singing, it is now also used to play an audio-book or to read scripts. As a tool to facilitate singing, karaoke is an activity intended to bring relaxation and excitement. This function of karaoke is then used to facilitate EFL learning which can bear lots of pressure. Using karaoke, students can listen to the music and read the lyrics in a relaxing way so that it is easier for them to practice the language elements being learned. Wodecki (2014) offered some reasons for using singing activities for improving pronunciation. First, songs are real-life examples of spoken English. Since they are full of rhymes, listeners can hear a number of similar sounds in a row. Moreover, learners are exposed to the sounds unconsciously because it is their choice to listen to the songs. Second, as lyrics also correspond with the melody they help learners realize how many syllables the words have, which syllable is stressed, and the rhythm of the language becomes rooted. Third, weak forms can be practice while listening and singing to songs, too. Thus, songs provide a great source for teaching weak and strong forms. Related to those arguments, karaoke seems to be a promising aid to attract students, and to achieve great goals helps them improve their pronunciation while having a good experience at the same time.

Based on his experience in using karaoke as a tool in the class, Erten (2015) proposed three points to consider: familiarity, individual differences and encouragement, and pedagogical objectives. Students' and teachers' familiarity with the classroom song chosen for karaoke singing is important to ensure active participation. An unfamiliar song can cause them to feel reluctant to participate in karaoke signing. Thus, selecting songs that students know can exert a positive impact on the effective use of karaoke in the class. Otherwise, the teachers need to initiate activities intended to familiarize the students with the song.

Encouragement is highly necessary because individuals may often exhibit varying levels of self-confidence about their voice and singing skills. Students, therefore, are not always equally courageous to sing aloud publicly. In addition, singing can also be an anxiety-provoking activity. Hence, students may need as much encouragement as they can get.

The third point, pedagogical objectives, concerns with the importance of a careful initial examination of the song lyrics so that they are suitable with the objectives of the lesson and motivating to the students as well. This consideration is necessary because karaoke singing carried out in the class often takes up valuable class-time.

Among the limited studies focusing on the use of karaoke to develop students' pronunciation, the study of Ulate (2008) revealed that the use of songs in the EFL classroom makes learning more enjoyable and interesting so that the students acquire the target language and feel comfortable in a relaxing atmosphere. It also helps the learners improve their understanding and production of important pronunciation features. Additionally, Rengifo (2009) conducted an action research project involving 12-15 Colombian adult EFL learners ranging aged 18-60 years to help them improve their English pronunciation using karaoke activities. Learning activities included talking about the song, listening to the teacher singing, the students singing (alone or in a group), and discussing the lyrics. At the end of the project, it was found that the use of karaoke improved the participants' pronunciation, increased their motivation and confidence, and reduced fear when speaking. 
The present study was primarily intended to investigate the effect of karaoke activities on EFL students' pronunciation. As stated earlier, the research question was stated as "Is there any significant effect of using karaoke activities on students' English pronunciation at 10th grade of SMA Negeri 14 Jakarta?" in relation to that, the hypothetical answers were formulated as follow.

$\mathrm{H}_{\mathrm{o}}$ : There is no significant effect of using karaoke activities on students' English pronunciation at 10th grade of SMA Negeri 14 Jakarta.

$\mathrm{H}_{\mathrm{a}}$ : There is a significant effect of using karaoke activities on students' English pronunciation at 10th grade of SMA Negeri 14 Jakarta.

\section{METHOD}

\section{Research Design}

This study is an experimental study that employs a one-group pretest-posttest design. It took one group only, i.e., an experimental class without any control class. Also, the pretest was administered at the beginning of the experiment before giving the treatment, and the post-test was given at the end of the treatment after finishing the last treatment.

The population in this research was the whole students of SMA Negeri 14 Jakarta in the academic year 2018/2019. Due to the administrative constraint, the sample was selected purposively, i.e. by taking X MIPA 3 class, consisting of 34 students as the experimental class. This research was conducted from April $9^{\text {th }}, 2019$ to June $16^{\text {th }}, 2019$, covering one pre-test, five times of treatment, and one post-test.

\section{Data Collection}

To collect the data, both pretest and posttest were administered by recording the students' utterance while they were doing speaking tests. The pretest was done to see the students' initial pronunciation competence, and the posttest was employed to find out the result of students' English pronunciation ability after learning pronunciation using karaoke activity. The posttest results were used to measure the effect of karaoke activity on the participants' English pronunciation. To determine each student's level of pronunciation performance, both pretest and posttest were evaluated employing the Evaluation Rubric for Pronunciation Activity (See Appendix 1).

\section{Data Analysis Technique}

The data obtained from the pre-test and post-test were analyzed using the descriptive analysis in the form of mean score. Before testing the hypothesis, the data was first tested using the Software Package for Social Science (SPSS) version 21.0 for windows to measure its normality and homogeneity. After that, a non-parametric analysis technique, i.e. Wilcoxon test, was administered to test the hypothesis.

\section{FINDINGS AND DISCUSSION}

\section{Participants' Initial Competence in English Pronunciation}

As shown by Table 1, the participants' initial competence in English Pronunciation was of medium level. The mean score of was 76.21, and the minimum and maximum scores were 67.00 and 82.00 respectively. 
Table 1

Statistic Description of Pre-Test Score in Experimental Class

\begin{tabular}{cccccc}
\hline \multirow{2}{*}{ Pre-Test } & Class & Mean & Minimum & Maximum \\
\cline { 2 - 5 } & X MIPA 3 & 76.21 & 67.00 & 82.00 \\
\hline & $\mathbf{X}$ & 76.21 & 67.00 & 82.00 \\
\hline
\end{tabular}

\section{Participants' Achievement in English Pronunciation}

As shown in Table 4.2, the mean score of the posttest was 79.68, and the minimum and maximum scores of the experimental class were 73.00 and 79.68 respectively.

Table 2

Statistic Description of Post-Test Score in Experimental Class

\begin{tabular}{cccccc}
\hline \multirow{2}{*}{ Post-Test } & Class & Mean & Minimum & Maximum \\
\cline { 2 - 5 } & X MIPA 3 & 79.68 & 73.00 & 82.00 \\
\hline & $\mathbf{X}$ & & 79.68 & 73.00 & 82.00 \\
\hline
\end{tabular}

\section{The Main Comparison of the Pre-test and Post-test}

Using the SPSS version 21.0 for windows, the researcher analyzed the data using the statistic descriptive analysis technique. As shown in Table 3, there was an increase in the participants' pronunciation performance after they went through the five time treatment using karaoke activities. The mean, minimum and maximum scores of the post-test were respectively $79.68 ; 73.00$; and 82.00 ; while those of the pre-test were respectively $76.21 ; 67.00$; and 82.00 .

Table 3

Statistic Description of Pre-Test and Post-Test Scores in Experimental Class

\begin{tabular}{ccccc}
\hline Class & Test & Mean & Minimum & Maximum \\
\hline \multirow{2}{*}{ Experimental } & Pre-Test & 76.21 & 67.00 & 82.00 \\
\cline { 2 - 5 } & Post-Test & 79.68 & 73.00 & 82.00 \\
\hline
\end{tabular}

\section{Hypothesis Test}

After the test for analysis requirements through the data normality and homogeneity had not met the criteria of each hypothesis, so the research hypotheses were tested using a non-parametric technique, i.e. the Wilcoxon Sign Ranks Test as an alternative test because the sample data were neither normal nor homogeneous. In order to test the hypotheses of this research, the Wilcoxon Sign Ranks Test was used to investigate the hypotheses of whether or not the alternative hypothesis of this research was accepted. The hypothesis criteria of the Wilcoxon Sign Ranks Test are: $\mathrm{H}_{\mathrm{o}}$ is accepted if Sig. (2tailed) value $\geq$ Sig. level $\alpha(0.05)$; while $\mathrm{H}_{\mathrm{a}}$ is accepted if Sig. (2-tailed) value < Sig. level $\alpha(0.05)$.

As shown in Table 4 which displays results of the Wilcoxon test, the Negative Ranks or difference (negative) between English pronunciation test result for pre-test and post-test is 0 . The value of N, Mean Rank and Sum of Ranks are also 0. The value of 0 shows no decrease (reduction) from the pre-test result to the post-test result. The Positive Ranks or the difference (Positive) between English pronunciation test result for 
pre-test and post-test. Here there are 31 positive data $(\mathrm{N})$, which means that 31 participants have increased the result of the English pronunciation test from the pre-test result to the post-test result. Mean Rank or the average increase is 16.00 , while the number of positive ranks or Sum of Ranks is 496.00. Ties are the same result of the pretest and post-test, here the test result is 3. Thus, it can be said that there are 3 participants who have equal result between the pre-test and post-test.

Table 4

Test Result of Wilcoxon Sign Ranks Test (Ranks)

\begin{tabular}{|c|c|c|c|c|c|}
\hline & & & $\mathrm{N}$ & Mean Rank & $\begin{array}{l}\text { Sum of } \\
\text { Ranks }\end{array}$ \\
\hline \multirow[t]{4}{*}{ Post-Test } & \multirow[t]{4}{*}{ Pre-Test } & Negative Ranks & $0^{a}$ & .00 & .00 \\
\hline & & Positive Ranks & $31^{b}$ & 16.00 & 496.00 \\
\hline & & Ties & $3^{c}$ & & \\
\hline & & Total & 34 & & \\
\hline
\end{tabular}

a. Posttest < Pretest

b. Posttest > Pretest

c. Posttest $=$ Pretest

As shown in Table 5, the Asymp. Sig. (2-tailed) is 0.000. Since the Sig. (2-tailed) (0.000) is lower than Sig. level $\alpha(0.05)$, it is determined that $\mathrm{H}_{\mathrm{o}}$ is rejected and $\mathrm{H}_{\mathrm{a}}$ is accepted. Therefore, it could be concluded that karaoke activities significantly affected the tenth graders' English pronunciation at SMA Negeri 14 Jakarta.

Table 5

Test Result of Wilcoxon Sign Ranks Test (Test Statistics ${ }^{a}$ )

\begin{tabular}{rr}
\hline & $\begin{array}{r}\text { Post-Test - } \\
\text { Pre-Test }\end{array}$ \\
\hline Z & $-4,875^{\mathrm{b}}$ \\
\hline Asymp. Sig. (2-tailed) & .000 \\
\hline
\end{tabular}

\section{CONCLUSIONS AND SUGGESTIONS}

Based on the research findings, it could be concluded that karaoke activities significantly affected the 10th graders' English pronunciation at SMA Negeri 14 Jakarta. It was indicated by the result of the Wilcoxon Signed Rank Test that the Sig. (2tailed) (0.000) is lower than Sig. level $\alpha(0.05)$, so that $\mathrm{H}_{\mathrm{a}}$ was accepted. Besides the result of the Wilcoxon Signed Rank Test, the mean scores of students showed an increase after the researcher applied karaoke activities in teaching, the students' achievement improved. Additionally, the use of karaoke activities could motivate and encourage the students' interest in learning English much better. The researcher also found that the students had a huge interest in karaoke activities on English songs. Therefore, karaoke activities are considered an effective technique in learning English especially English Pronunciation.

Considering the findings and conclusions above, teachers are recommended to explore many interesting techniques to motivate the students in learning English and to change the monotonous teaching-learning activity. In this context, karaoke activities are an effective alternative for this technique was managed to enable students to get better 
performance. Besides, by using this technique, the teachers are also able to create a cheerful atmosphere in learning English to make the students enjoy and are interested to study.

Since this study employed one-group pretest-posttest design and the sample was selected purposively, the results have several limitations to generalize to a larger population. Therefore, further researchers are recommended to conduct experiments with both control and experimental groups and participants randomly selected from a larger population. In order to get a deeper and more comprehensive understanding of the use of karaoke activities to develop learners' pronunciation, conducting studies which also collect qualitative data required to investigate the students and teachers' perception of the practice is also recommended.

\section{References}

Adams-Goertel, R. (2013). Prosodic elements to improve pronunciation in English language learners: A short report. Applied Research on English Language, 2(2), 117-128.

Arleo, A. (2000) Music, Song and Foreign Language Teaching. In Cahiers de i'APLIUT, 19(4), pp. 5-19; DOI: https://doi.org/10.3406/apliu.2000.3005

Carlsson, L. (2015). Singing as a tool for English pronunciation improvement. LUP Student Papers, 1 - 22. Retrieved from https://lup.lub.lu.se/studentpapers/search/publication/8889424

Chen, J.-J. (2011). The effects of music activities on English pronunciation and vocabulary retention of fourth-grade ESOL (English for speakers of other languages) students in Taiwan (Doctoral dissertation, The University of Florida, Florida, United Stated), Florida. Retrieved from https://ufdc.ufl.edu/UFE0042744/00001

Dalton, D. (2002). Some Techniques for Teaching Pronunciation. Retrieved from http://iteslj.org/Techniques/Dalton_Pronunciation.htm

Derwing, T.M.,\&Munro, M.J.(2005).Second language accent and pronunciation teaching: A research-based approach. TESOL Quarterly, 39, pp. 379-397. http://dx.doi.org/10.2307/3588486

Donal, A. (2016). Indonesian students' difficulties in pronouncing English diphthongs. Journal of English Education, 2(2), 55. Retrieved from https://www.academia.edu/37071798/INDONESIAN_STUDENTS_DIFFICULTI ES_IN_PRONOUNCING_ENGLISH_DIPHTONGS

Erten, I.H. (2015). Using karaoke in language classrooms: Exploring potentials and prospects. Procedia - Social and Behavioral Sciences, 199, pp. 589 - 596

Fraser, H. (2000). Coordinating Improvements in Pronunciation Teaching for Adult Learners of English as a Second Language. University of New England, Armidale, NSW.

Gilakjani, A.P. (2012). A Study of Factors Affecting EFL Learners' English Pronunciation Learning and the Strategies for Instruction. International Journal of Humanities and Social Science, 2(3), 119-128.

Gilakjani, A.P. \& Sabouri, N.B. (2016). Why Is English Pronunciation Ignored by EFL Teachers in Their Classes? International Journal of English Linguistics, 6(6), pp. 195-208.

Gilbert, J. B. (2008). Teaching Pronunciation Using the Prosody Pyramid. New York: Cambridge University Press. 
Harmer, J. (2000). The Practice of English language teaching. London: Longman Group Ltd.

Hinkel, E. (Ed.). 2005. Handbook of research in second language teaching and learning. New Jersey: Lawrence Erlbaum Associates, Inc.

Hişmanoğlu, M. (2006). Current perspectives on pronunciation learning and teaching. Journal of Language and Linguistic Studies, 2(1), 101-110.

Julia, G. (2002). Introducing English rhythm in Chinese EFL classrooms: A Literature Review. Published by the Faculty of Education at the University of Melbourne, Australia. 3(1), 26-42

Lems, K. (2001). Using music in the adult ESL classroom. ERIC Digest, Document No: ED459634.

Lin, H., Fan, C., \& Chen, C. (1995). Teaching Pronunciation in the Learner-Centered Classroom. (ERIC Document Reproduction Service No. ED393292).

McCall, W. G. (2008). Same-language-subtitling and karaoke: The use of subtitled music as a reading activity in a high school special education classroom. Society for Information Technology \& Teacher Education International Conference, 2008(1), 1190-1195.

Moedjito. (2008). Priorities in English pronunciation teaching in EFL classrooms. $k @ t a$ Journal, 16(2), 129-142.

Morley, J. (1991) The Pronunciation Component in Teaching English to Speakers of Other Languages. TESOL Quarterly 25/1 51-74.

Pardede, P. (2019). Employing Music and Songs in EFL Classrooms. In: PROCEEDING English Education Department Collegiate Forum (EED CF) 2015-2018. UKI Press, Jakarta, pp. 251-264. ISBN 9786237256250

Pardede, P. (2018). Improving EFL students' English pronunciation by using the explicit teaching approach. Journal of English Teaching, 4(3), 143-155. DOI: http://dx.doi.org/10.33541/jet.v4i3.852

Pardede, P. (2007). The Role of Pronunciation in a Foreign Language Program. Jakarta: Universitas Kristen Indonesia. Retrieved March 2019 from https://parlindunganpardede.wordpress.com/2010/10/07/349/

Pare, K. B. (2015). Pentingnya pronunciation dalam bahasa Inggris. Retrieved from http://kursusbahasainggristhebenefit.blogspot.com/2015/05/pentingnyapronunciation-dalam-bahasa.html

Pennington, M. C., \& Revell, P. R. (2019). English pronunciation teaching and research. London: Springer Nature Limited.

Rengifo, A. R. (2009). Improving pronunciation through the use of karaoke in an adult English class. Profile Issues in Teachers Professional Development, 11, 91-106.

Richard, J. C. \& Renandya, W.A. (2002). Methodology in Language Teaching. Cambridge: Cambridge University Press.

Ulate, N.V.. (2008). Using Songs to Improve EFL Students' Pronunciation. LETRAS, (44), 93-108. $\quad$ Retrieved $\quad$ February 2019 from https://www.revistas.una.ac.cr/index.php/letras/article/view/264

Wei, Y., \& Zhou, Y. (2002). Insights into English Pronunciation Problems of Thai Students. (ERIC Document Reproduction Service No. ED476746)

Wong, P and Perrachione, T (2006), Learning pitch patterns in lexical identification by native English speaking adults. Applied Psycholinguistics. Abstract available at http://tiny.cc/WongPerachione2006Pitch 
Yates, L. (2002). Pronunciation 1. La Trobe: Adult Migrant English Program Research Centre.

Yates, L., \& Zielinski, B. (2009). Give it a go: Teaching Pronunciation to Adults. AMEP Research Centre, Department of Immigration and Citizenship, Macquarie University, Sydney, Australia.

Zhang, F., \& Yin, P. (2009). A study of pronunciation problems of English learners in China. Asian Social Science, 5(6), 141. Retrieved from https://pdfs.semanticscholar.org/4732/7dad6066a0a6aa1e37a83b5ac8a5d236a583. pdf

\section{Appendix 1}

The Evaluation Rubric for Pronunciation Activity

\begin{tabular}{|c|c|c|c|c|}
\hline & $\begin{array}{c}\text { Excellent } \\
(10)\end{array}$ & $\begin{array}{c}\text { Good } \\
(9-8)\end{array}$ & $\begin{array}{c}\text { Satisfactory } \\
(7-6)\end{array}$ & $\begin{array}{l}\text { Poor } \\
(5-4)\end{array}$ \\
\hline Voice & $\begin{array}{l}\text { Student's voice has } \\
\text { an excellent volume } \\
\text { to be heard clearly }\end{array}$ & $\begin{array}{l}\text { Student's voice has a } \\
\text { good volume to be } \\
\text { heard }\end{array}$ & $\begin{array}{l}\text { Student's voice has a } \\
\text { poor volume, it is } \\
\text { difficult to be } \\
\text { heard clearly }\end{array}$ & $\begin{array}{l}\text { Student's voice has a } \\
\text { very poor volume, it } \\
\text { can hardly be heard }\end{array}$ \\
\hline Intonation & $\begin{array}{l}\text { Student's inflections } \\
\text { and } \\
\text { intonation (varying } \\
\text { the tone of the voice) } \\
\text { in each } \\
\text { expression are } \\
\text { excellent }\end{array}$ & $\begin{array}{l}\text { Student's inflections } \\
\text { and intonation } \\
\text { (varying the tone of } \\
\text { the voice) in each } \\
\text { expression are good }\end{array}$ & $\begin{array}{l}\text { Student's inflections } \\
\text { and intonation } \\
\text { (varying the tone of } \\
\text { the voice) in } \\
\text { each expression are } \\
\text { poor }\end{array}$ & $\begin{array}{l}\text { Student's inflections } \\
\text { and intonation } \\
\text { (varying the tone of } \\
\text { the voice) in } \\
\text { each expression are } \\
\text { very poor }\end{array}$ \\
\hline $\begin{array}{l}\text { Pronunciation } \\
\text { and clarity }\end{array}$ & $\begin{array}{l}\text { Student pronounces } \\
\text { all the words } \\
\text { correctly }\end{array}$ & $\begin{array}{l}\text { Student pronounces } \\
\text { most of the words } \\
\text { correctly (missing } \\
\text { under } 5 \text { words) }\end{array}$ & $\begin{array}{l}\text { Student does not } \\
\text { pronounce most } \\
\text { of the words correctly } \\
\text { (missing around 6-15 } \\
\text { words) }\end{array}$ & $\begin{array}{l}\text { Student does not } \\
\text { pronounce most } \\
\text { of the words correctly } \\
\text { (missing around 16- } \\
25 \text { words) }\end{array}$ \\
\hline
\end{tabular}

Retrieved from :

http://englishutim.weebly.com/uploads/2/3/4/0/23405494/audiorecordingevaluationrubric.pdf 